\section{Museum's plans beyond belief}

SIR - I read with disbelief your recent leading article (Nature 345, 1; 1990) and letters from colleagues regarding the British Natural History Museum's corporate plan announced on 23 April.

Museums have two important functions and the great ones do both: (1) museums are centres for empirical research on the material evidence of diversity and development of a subject, be it art or science, and (2) museums are centres for exhibition of evidence, enriching information available in books, films and classrooms to substantiate a grander world beyond access to the average reader/viewer/ student. Research develops the meaning of this evidence in its widest possible context, and exhibition substantiates the credibility of book and classroom learning for the public at large.

I have worked regularly in the Natural History Museum for many years, long enough to have seen it change. The greatest change has been in the exhibition programme where exhibits increasingly duplicate information available in books, films, classrooms and television - less often featuring specimens and I-can-see-it evidence of diversity and development in natural history. Exhibits are expensively and extravagantly dominated by action and colour befitting entertainment centres rather than an educational institutions.

If research and exhibition cannot be brought into better balance, sound corporate management suggests research collections might be given away (or better sold) to speed convergence with Disneyland. Americans and Germans and Japanese have always coveted the Natural History Museum's research collections (and the extraordinary natural history learned from these) so there shouldn't be a problem finding buyers. Students can always travel overseas if they really want to learn about nature.

PHILIP D. GINGERICH

University of Michigan,

Museum of Paleontology,

Ann Arbor, Michigan 48109-1079, USA

SIR-In a recent article about the cuts in scientific posts at the Natural History Museum' it was reported that one of us (K.A.J.) had "condemned the cuts as 'ludicrous"". This terse comment was not intended to imply a judgement on each and every one of the cuts. In order to capture the intended nuance it needs to be amplified to read: "condemned the financial situation which has led to the cuts as "ludicrous"”.

At a time when there is a widespread concern for the loss of biodiversity, it has come to be realized that perhaps 90 per cent of species remain unknown to science. In order to remedy this, it has been suggested that the number of taxonomists needs to be increased about twenty-five-fold ${ }^{2}$. But systematic biology is being run down ${ }^{3}$ : it is fast disappearing from institutions of higher education as it ceases to attract funding ${ }^{4.5}$, and the universities are not in a position to appoint taxonomists if they are to fulfil their commitment to other, more costly, areas of biology.

We believe that the crisis confronting systematic biology (including taxonomy, palaeontology and comparative morphology) in Britain is now so grave that new initiatives are called for. Rather than just deploring the cuts, we offer the following positive proposals.

(1) Pursue the suggestion ${ }^{6}$ that the Linnean Society - the one national learned society serving the interests of the whole of biology - might set up investment funds to establish research fellowships which should, at least initially, give priority to systematic biology. Can funds be generated by an appeal to commercial organizations? A large pump-priming grant from central government would set an example, and indicate that it has received the message that basic taxonomic studies are an essential prerequisite to responsible management of the environment.

(2) The Natural Environment Research Council (NERC) should establish a committee to support systematic biology. Furthermore, NERC needs to reformulate its guidelines to allow the granting of funds for salaries for research workers in systematic biology who do not already hold salaried posts. Most research in these fields does not require expensive equipment: the impediment is the lack of salaries.

(3) The authorities should be persuaded to provide the resources necessary to allow the Natural History Museum to maintain its position as the international centre of excellence in systematic biology.

K. A. JOYSEY, J. A. CLACK, M. I. COATES, R. H. L. Disney, W. A. Foster, A. E. Friday, A. M. LISTER \& R. C. PREECE University Museum of Zoology,

\section{Downing Street,}

Cambridge CB2 3EJ, UK

1. Gee, H. Nature 345, 4 (1990).

2. Holden, C. Science 246, 754-756 (1989)

3. Black, C.C. (Chairman) Natn. Sci. Fdn., Natn. Sci. Board, Natn. Rep. 89-171, 1-19 (1989).

4. Disney, R. H. L. Linnean 6(1), 12-14 (1990)

5. Ehrenfeld, D. Conservation Biol. 3, 415 (1989)

6. Erzinclioglu, Y. Z. \& Fraser, N. C. Linnean 6(2), 9-10 (1990).

SIR-When I suggested two years ago (Nature 333, 292; 1988) that "the current performance behind the turnstiles and showcases of this national institution turned scientific Disneyland in relation to its past traditions and promises [needs] more public scrutiny", it did not occur to me that the next director of the British Museum (Natural History) might take the comparison seriously and decide he could get away with it. Even six months ago, he was still professing that "the Natural History Museum will move on to ensure that the museum retains its position as one of the world's great research-based museums of natural history. Its magnificent collections and the curatorial expertise of its scientific staff will continue to provide the foundation for its science. . ." (Neil Chalmers, Times, 29 November 1989). It may therefore be of interest to consider the implications of the recent cuts.

Last autumn, I asked my MP, Alick Buchanan-Smith, to take up with the minister the declining standard of service in the subdepartment of ornithology, which suffered severely in an earlier round of cuts, after I had made a journey down from Scotland to pick up some documents deposited in the subdepartment and found that they were not ready. Richard Luce replied on 6 November that "in the last week approval has been given for the appointment of an additional junior curator and I am sure that this will help the Department to deal with enquiries". When I returned a couple of weeks ago I was therefore surprised to find that they were still so short-staffed that they had to close at lunchtime, and discovered that they had apparently attempted to fill this vacancy by advertising in the local newspaper, whereupon the only potentially suitable applicant had rapidly decided to accept a more attractive offer elsewhere.

I was concerned to find that my previous complaints of a declining standard of service in a subdepartment affected by past cuts have been misrepresented as criticism of the surviving staff, who are continuing to do their best under deteriorating conditions. I do not wish to criticize them. But it may still may be questioned how long they will be able to maintain even the present standard if this is the way in which it is proposed to try and replace the doctors of philosophy apparently declared redundant so that the museum can masquerade as expert in more fashionable fields where it has previously made little contribution. Although it is interesting to observe that the staff in the main museum at South Kensington are at last beginning to show some solidarity in resisting further cuts there, one could have wished that together with our universities they had shown a little more unanimity at the start of the process of attrition, instead of allowing it to proceed to the lengths that you have now described.

Department of Zoology, W. R. P. BOURNE

University of Aberdeen,

Tillydrone Avenue,

Aberdeen AB9 2TN, UK 